\title{
Effects of Different Level of Nitrogen Fertilizer Application on Growth, Yield, Quality and Storage Life of Onion (Allium cepa L.) at Jimma, South Western Ethiopia
}

\author{
Muluneh Bekele Etana (Ass. Professor) \\ Ambo University, College of Agriculture and Veterinary Science, Department of Horticulture \\ Alli Mohammed $(\mathrm{PhD})$ \\ Jimma University, College of Agriculture and Veterinary Medicine, Department of Horticulture \\ Amsalu Nebiyu (PhD) \\ Jimma University, College of Agriculture and Veterinary Medicine, Department of Horticulture
}

\begin{abstract}
Onion (Allium cepa L.) is one of the most important vegetable crops produced in Ethiopia. Yield and productivity of the crop has been far below the regional and national standards owing to several factors; absence of location specific fertilizer recommendation being the major among others. In Ethiopia, post harvest loss of vegetables contributed up to $30 \%$ yield reduction. Thus, a field experiment was conducted at Jimma University College of Agriculture and Veterinary Medicine Research field during dry season to study the effects of Nitrogen fertilizer application on growth, yield, quality and storage life of irrigated onion under Jimma condition, South Western Ethiopia. The treatments consisted of four levels of Nitrogen $\left(0,50,100\right.$ and $\left.150 \mathrm{~kg} \mathrm{~N} \mathrm{ha} \mathrm{a}^{-1}\right)$ that laid out in Randomized Complete Block Design with three replications. Data on growth, yield, bulb quality and storage life parameters were recorded and analyzed using GenStat 12.1 version computer soft ware packages. Results of the study revealed that; Nitrogen fertilizer applications had shown a highly significant effect on growth, yield and quality of onion. Similarly, the keeping qualities of the Onion bulbs are highly influenced by application of $\mathrm{N}$ at different levels. Excessive application of Nitrogen fertilizer caused higher bulb rots (\%); bulb sprouts (\%) and weight loss (\%) during the three month storage time at ambient temperature. This can be recommended for use by potential onion investors or farmers in the study area.
\end{abstract}

Keywords: Growth, Nitrogen, Onion, Quality, Storage life, Yield.

DOI: $10.7176 / \mathrm{JNSR} / 9-10-05$

Publication date:May $31^{\text {st }} 2019$

\section{INTRODUCTION}

Onion was introduced to the agricultural community of Ethiopia in the early 1970's when foreigners brought it in. Though shallots were traditional crop in Ethiopia, Onion is becoming more widely grown in recent years. Currently, the crop is produced in different parts of the country for local consumption and for export of flowers to European markets (Lemma and Shimelis, 2003).

Onion is considerably important in the daily Ethiopian diet. All the plant parts are edible, but the bulbs and the lower stem sections are the most popular as seasonings or as vegetables in stews (MoARD, 2009). It is one of the richest sources of flavonoids in the human diet and flavonoid consumption has been associated with a reduced risk of cancer, heart disease and diabetes. Flavonoids are not only anti-cancer, but also are known to be anti bacterial, antiviral, anti-allergenic and anti-inflammatory. One Onion quality parameter, the percentage of single center bulbs, has become important to meet demands of both processing and fresh market buyers (Brewster, 1990 and Pelter, 2004).

Different cultural practices are known to influence yield and quality of dry bulb. So far, research in the country was mainly focused on the identification of superior cultivars of onions but mineral nutrition is main factors that affect growth, yield and quality of onion (Chung, 1989). Nitrogen mineral nutrient is often referred to as the primary macronutrients because of the probability of plants being deficient in these nutrients and because of the large quantities taken up by plants from the soil relative to other essential nutrients (Marschner, 1995). Nitrogen comprises $7 \%$ of total dry matter of plants and is a constituent of many fundamental cell components (Bungard et al., 1999). It is one of the most complexes in behavior, occurring in soil, air and water in organic and inorganic forms. For this reason, it poses the most difficult problem in making fertilizer recommendations (Archer, 1988). Plant demand for Nitrogen nutrient can be satisfied from a combination of soil and fertilizer to ensure optimum growth. Onion is more susceptible to nutrient deficiencies than most crops because of their shallow and unbranched root system; hence they require and often respond well to addition of fertilizers (Brewester, 1994).

A number of production constraints are responsible for such reduced bulb yield, quality and storage life of which lack of specific fertilizer recommendation for the area is in the top list. Better understanding of the nutrient 
requirements of Onion plant is needed in order to develop management strategies, which optimize fertilizer use of the crop and thereby increase returns with premium bulb qualities to the producers. Moreover, improved fertilizer management for Onion may help to improve quality, particularly bulb size and storability, and thus offer growers premium prices. Hence there is an urgent need to identify the optimum Nitrogen nutrient level for better productivity, bulb quality and storage life of Onion in the area. In the light of the above, the study was undertaken to determine the optimum level of $\mathrm{N}$ fertilizer for optimum growth, yield, bulb quality and storage life of Onion (Allium cepa L.) at Jimma, South Western Ethiopia.

\section{MATERIALS AND METHODS}

\section{Description of the study area}

The experiment was conducted under field condition at Jimma University College of Agriculture and Veterinary Medicine research field under irrigation condition. Jimma University College of Agriculture and Veterinary Medicine is geographically located $346 \mathrm{~km}$ southwest of Addis Ababa at about $7^{0}, 33^{\prime} \mathrm{N}$ latitude and $36^{\circ}, 57^{\prime} \mathrm{E}$ longitude and an altitude of 1710 meter above sea level. The analysis of soil samples from the top $30 \mathrm{~cm}$ depth of the experimental site before the experiment was done. The mean maximum and minimum temperatures are $26.8^{\circ} \mathrm{C}$ and $11.4^{\circ} \mathrm{C}$, respectively and the mean maximum and minimum relative humidities are $91.4 \%$ and $39.92 \%$, respectively. The mean annual rainfall of the area is $1500 \mathrm{~mm}$ (BPEDORS, 2000).

Table1. Soil physical and chemical properties of the experimental site

\begin{tabular}{ll}
\hline Characteristics & Units \\
Sand & $8 \%$ \\
Silt & $44 \%$ \\
Clay & $48 \%$ \\
Textural class & Silty clay \\
Organic carbon & $1.46 \%$ \\
Total nitrogen & $1.42 \%$ \\
pH $1: 1$ water & 5.94 \\
Electric conductivity $(1: 1)$ & $53.1(\mu \mathrm{S} / \mathrm{cm})$ \\
Available P $(\mathrm{ppm})$ & $2.80 \mathrm{ppm}$ \\
Bulk density $(\mathrm{g} / \mathrm{cm} 3)$ & 1.58 \\
\hline
\end{tabular}

The Soil Physical and chemical properties of experimental site were done at Jimma Agriculture Research center and Jimma University College of Agriculture and Veterinary Medicine soil laboratory.

\section{Experimental Materials}

The experiment consisted of three types of fertilizer in different levels, which were Nitrogen $(\mathrm{N})$ at four levels. Onion (Allium cepa L.) variety Bombay Red was used. The seed was collected from Melkessa Agricultural Research Center.

Table 2: Details of Onion variety used in the study

\begin{tabular}{l|ccc|c}
\hline Variety Name & \multirow{2}{*}{$\begin{array}{l}\text { Year of } \\
\text { release }\end{array}$} & \multicolumn{2}{|c|}{ Area of adaptation } & \multirow{2}{*}{$\begin{array}{c}\text { Days to } \\
\text { maturity }\end{array}$} \\
\cline { 3 - 4 } & & Altitude $(\mathrm{m})$ & Rain fall $(\mathrm{mm})$ & (19) \\
\hline Bombay Red & 1980 & $700-2000$ & Irrigated & $<120$ \\
\hline
\end{tabular}

Source: - EARO (2004)

\section{Experimental Design and Layout}

The experiment was laid out in a 4x3 arrangement in a Randomized complete Block Design (RCBD) with three replications. The treatments were randomly assigned to the experimental plots. Onion seedlings were raised on a well prepared seedbed whose dimension was $5 \mathrm{mX} 1 \mathrm{~m}$. The seeds were sown in rows marked $15 \mathrm{~cm}$ interval across the length of the seed bed and the beds were covered with dry grass mulch until emergence. Complete germination of the seeds took place within 7 to 10 days of sowing and seedlings were thinned out after three weeks in order to maintain optimum plant population and to keep them vigorous. Watering of the seed bed was done always in the morning and afternoon using watering can.

The seed beds were watered before uprooting the seedlings in order to minimize the damage of the roots. Healthy, uniform and 52 days old seedlings were transplanted to the prepared field at spacing of $20 \mathrm{~cm}$ between rows and $10 \mathrm{~cm}$ between plants was used according to the EARO, 2004 recommendation. Finally, the seedlings were watered after transplanting and $50 \%$ of each levels of the $\mathrm{N}$ as UREA (46\%) were side dressed and the remaining $50 \%$ of each levels of $\mathrm{N}$ was applied after a month of transplanted date. Weeds were controlled mechanically (by hand weeding). The plots were irrigated daily until maturity.

The size of each plot was $1.2 \mathrm{~m}^{2}(1 \mathrm{~m} \mathrm{x} 1.2 \mathrm{~m})$. All the 12 treatments combinations were randomly assigned 
to the unit plot of each block so as to allot one treatment combination only once in each block. There were 10 plants in each row and 60 plants per plot. A foot path of $0.5 \mathrm{~m}$ and $1 \mathrm{~m}$ were left between plots and replications, respectively. Mancozeb were applied three times to prevent the damage by of Fungi due to the humid weather condition at rate of $4.0 \mathrm{~kg}$ per ha with mixing 600 liter of clean water. All other agronomic management practices were provided as per the recommendation equally for all the treatments (Getachew et al., 2009).

Lastly, bulbs from the central four rows were harvested after $60 \%$ top part fall and used for analysis. Curing bulb was done for ten days under partial shade and ten sample bulbs were taken to storage room. Bulbs were stored in naturally ventilated house constructed from mesh wire wall and corrugated iron sheet roofing. Daily storage room temperature and relative humidity was recorded using hand Psychrometer and the average daily maximum and minimum temperature during the two month storage periods were used.

\section{Statistical Analysis}

The parameters considered in this study were subjected to statistical analysis. Analysis of variance (ANOVA) was done using GenStat versions12.1 (VSN International, 2008) with the REML variance component analysis. Mean difference were tested following least significant difference (LSD) at $(\mathrm{P} \leq 0.05)$. Interpretations and use of some biometrical equations were made according to Gomez and Gomez (1984).

\section{RESULTS AND DISCUSSIONS \\ Growth Parameters \\ Plant height}

Application of $\mathrm{N}$ had shown a highly significant $(\mathrm{p}<0.001)$ effect on mean plants height at physiological maturity. The highest mean value $(49.59 \mathrm{~cm})$ was recorded from the plot that received $150 \mathrm{~kg}$ of $\mathrm{N} \mathrm{ha} \mathrm{H}^{-1}$. Respect less of levels, maximum application of $\mathrm{N}$ at $150 \mathrm{~kg} \mathrm{ha}^{-1}$ increased the mean plants height by about $12 \%$ as compared to the control $(43.84 \mathrm{~cm})$. The increase in height at increased application of $\mathrm{N}$ could be attributed to its involvement as building blocks in the synthesis of amino acids, as they link together and form proteins and make up metabolic processes required for plant growth. Similar results have been reported by Amans et al. (1996), Kumar et al. (1998), Khan et al. (2002), El-Shaikh (2005), Shaheen et al. (2007) and Abdissa et al. (2011).

\section{Leaf length}

A highly significant variation $(\mathrm{p}<0.001)$ in the leaf length $(\mathrm{cm})$ was observed at the application of $\mathrm{N}$ treatments. The highest mean value $(39.84 \mathrm{~cm})$ was obtained from the plot that received $150 \mathrm{~kg} \mathrm{of} \mathrm{N}$ ha ${ }^{-1}$. Maximum application of $\mathrm{N}$ at $150 \mathrm{~kg} \mathrm{ha}^{-1}$ increased mean leaf length per plants by about $16 \%$ when compared to control $(33.51 \mathrm{~cm})$. The positive effect of $\mathrm{N}$ on leaf length may be due to its role on chlorophyll, enzymes and proteins synthesis. The results of this study are in agreement with finding of Jilani (2004) who reported that, application of $200 \mathrm{~kg} \mathrm{~N} \mathrm{ha}^{-1}$ significantly enhanced the length of onion leaves. Similarly, Kumar et al. (1998) and Singh and Chaure (1999) indicated that application of $\mathrm{N}$ at $150 \mathrm{~kg} \mathrm{ha}^{-1}$ gave the best result with the regard to onion leaf length. Similarly Abdissa et al. (2011) also reported that $\mathrm{N}$ application showed significant effect on onion leaf length.

\section{Leaf sheath (shaft) length}

Without considering the levels, maximum application of $\mathrm{N}$ at $150 \mathrm{~kg} \mathrm{ha}^{-1}$ increased the mean leaf sheath length by about $23 \%$ as compared with the unfertilized plot $(5.09 \mathrm{~cm})$. This could be shows that nitrogen plays an important role in leaf sheath length via its role in vegetative growth. These results are in conformity with the findings of Khan et al. (2002) who reported that number of leaves per plant increased with increasing nitrogen level up to 150 $\mathrm{kg} \mathrm{ha}^{-1}$ which is also similar for leaf sheath length.

\section{Percentage of bolters}

Percentage of bolted plants was highly significantly affected by $\mathrm{N}$ application. All the levels of $\mathrm{N}$ showed a highly significant $(\mathrm{p}<0.001)$ difference on Onion percentage of bolted. Increased levels of $\mathrm{N}$ fertilization significantly reduced the bolting percentage. The proportion of percentage bolted decreased by about $15 \%, 36 \%$ and $59 \%$ in response to the application of 50,100 and $150 \mathrm{~kg}$ of N ha-1, respectively over the control treatments. This could be associated with the effect of $\mathrm{N}$ in extending the vegetative growth period of plants while delaying flowering. The findings of this investigation are in close conformity with those Yamasaki and Tanaka, (2005) who reported that, in Allium fistulosum L. low Nitrogen promoted bolting in onion plants. Abdissa et al. (2011) also reported similar results. As a general, significantly higher bolting percentage was observed on the control plants than the fertilized plants, which may be linked to limitation of $\mathrm{N}$.

\section{Bulb Yield Parameters \\ Bulb diameter and Bulb length}

Application of $\mathrm{N}$ at different levels had shown a highly significant $(\mathrm{P}<0.001)$ difference on mean bulb diameter and length of Onion plants. Regardless of levels, maximum fertilization of $\mathrm{N}$ at $150 \mathrm{~kg} \mathrm{ha}^{-1}$ increased the mean bulb diameter by about $13 \%$ in reference to the control treatments $(5.22 \mathrm{~cm})$. Larger bulb diameter with higher yield in Onion due to $\mathrm{N}$ application is likely as because Nitrogen encourages cell elongation, above ground 
vegetative growth and to impart dark green color of leaves which may be linked to the increase in dry matter production and allocation to the bulb (Brady, 1985). This result is sustaining Nasreen et al. (2007) who reported that a significant increase in the mean diameter of bulbs due to the application of $\mathrm{N}$ up to $120 \mathrm{~kg} \mathrm{ha}^{-1}$. Similar results also reported by Yadav et al. (2003) who found that $\mathrm{N}$ at $150 \mathrm{~kg} \mathrm{ha}^{-1}$, enhanced the formation of bulbs with larger diameters. Kumar et al. (1998), Khan et al. (2002) and Abdissa et al. (2011) also reported that bulb diameter is significantly affected by the application of $\mathrm{N}$.

Table 1: Effect of $N$ fertilization on bulb length and bulb diameter

\begin{tabular}{lll}
\hline Treatments & Bulb diameter $(\mathbf{c m})$ & Bulb length $(\mathbf{c m})$ \\
\hline Nitrogen $\left(\mathrm{kg} \mathrm{ha}^{-1}\right)$ & & \\
0 & $5.21^{\mathrm{c}}$ & $4.42^{\mathrm{c}}$ \\
50 & $5.35^{\mathrm{c}}$ & $4.53^{\mathrm{c}}$ \\
100 & $5.75^{\mathrm{b}}$ & $4.96^{\mathrm{b}}$ \\
150 & $6.02^{\mathrm{a}}$ & $5.23^{\mathrm{a}}$ \\
\hline SE(+) & 0.059 & 0.047 \\
LSD & 0.232 & 0.202 \\
CV (\%) & 8.89 & 9.01 \\
\hline
\end{tabular}

Means in a column followed by the same letter(s) are not significantly different at $5 \%$

Mean bulb weight

There was statistically highly significant $(\mathrm{p}<0.001)$ difference in mean bulb weight due to application of $\mathrm{N}$ at different levels. The maximum application of $\mathrm{N}$ at a rate of $150 \mathrm{~kg} \mathrm{ha}^{-1}$ increased the mean bulb weight by about $17 \%$, as compared to the control treatments $(41.35 \mathrm{~g})$. The mean bulb weight improvement in response to $\mathrm{N}$ application could be attributed to the increase in plant height, number of leaves produced, Leaf diameter, leaf length, and extended physiological maturity in response to the fertilization all might have increased assimilate production and allocation to the bulbs. Similarly, Kashi and Frodi (1998), Greenwood et al. (2001), Khan et al. (2002) and Abdissa et al. (2011) reported that significant increase in bulb weight due to increased $\mathrm{N}$ application.

Table 2: Mean bulb weight of onion per plant as influenced by applications of $N$

\begin{tabular}{lc}
\hline Treatments & Mean bulb weight $(\mathrm{g})$ \\
\hline Nitrogen $\left(\mathrm{kg} \mathrm{ha}^{-1}\right)$ & \\
0 & $41.35^{\mathrm{d}}$ \\
50 & $43.37^{\mathbf{c}}$ \\
100 & $46.82^{\mathbf{b}}$ \\
150 & $49.78^{\mathbf{a}}$ \\
\hline SE $( \pm)$ & 0.84 \\
LSD & 1.791 \\
CV $(\%)$ & 8.45 \\
\hline
\end{tabular}

Means in a column followed by the same letter(s) are not significantly different at $5 \%$

\section{Marketable bulb yield}

Regardless of levels, maximum application of $\mathrm{N}$ at $150 \mathrm{~kg} \mathrm{ha}^{-1}$ increased the marketable bulb yield. This finding is in consistent with the result of Girigowda et al., (2005) who recorded that the higher marketable bulbs yield (41.69 t/ha) was recorded with fertilizer level of 188:75:188 $\mathrm{kg}_{\mathrm{g}}$ of NPK ha ${ }^{-1}$.

Table 3: Effect of $N$ fertilizers on Marketable bulb yield

\begin{tabular}{ll}
\hline Treatments & Marketable bulb yield/ ha (tons) \\
\hline Nitrogen $\left(\mathbf{k g ~ h a}^{-1}\right)$ & \\
0 & $12.31 \mathbf{d}$ \\
50 & $13.60 \mathbf{c}$ \\
100 & $15.89 \mathbf{b}$ \\
150 & $16.93 \mathbf{a}$ \\
\hline SE $( \pm)$ & 0.1084 \\
LSD & 0.2524 \\
\hline CV $(\%)$ & 14.08 \\
\hline
\end{tabular}

Means in a column followed by the same letter(s) are not significantly different at $5 \%$

\section{Unmarketable bulb yield}

$\mathrm{N}$ had shown a highly significant $(\mathrm{P}<0.001)$ difference on the unmarketable bulb yield $(\mathrm{t} / \mathrm{ha})$. The result indicates that higher application of $\mathrm{N}$ decreased the unmarketable bulb yield per hectare and the highest unmarketable bulb yield was recorded in the unfertilized plots in all treatments. Without considering the levels, maximum application of $\mathrm{N}$ at rate of $150 \mathrm{~kg} \mathrm{ha}^{-1}$ decreased the unmarketable bulb yield per hectare by about $5.2 \%$ as compared to the unfertilized plot. 
Table 4: The influence of different rates of $N$ on Unmarketable bulb yield ha-1

\begin{tabular}{ll}
\hline Treatments & Unmarketable bulb yield/ha (ton) \\
\hline Nitrogen $\left(\mathrm{kg} \mathrm{ha}^{-1}\right)$ & \\
0 & $0.98^{\mathbf{a}}$ \\
50 & $0.78^{\mathbf{b}}$ \\
100 & $0.63^{\mathbf{c}}$ \\
150 & $0.47^{\mathbf{d}}$ \\
\hline SE $( \pm)$ & 0.036 \\
LSD $(\mathbf{0 . 0 5})$ & 0.072 \\
CV $(\%)$ & 21.38
\end{tabular}

Means in a column followed by the same letter(s) are not significantly different at 5\%

Total bulb yield

$\mathrm{N}$ had shown a highly significant $(\mathrm{P}<0.001)$ difference on the bulb yield $(\mathrm{t} / \mathrm{ha})$. The result indicates that higher application of $\mathrm{N}$ increased the bulb yield per hectare and the highest bulb yield $(17.41 \mathrm{t} / \mathrm{ha})$ was recorded in the $150 \mathrm{~kg} \mathrm{ha}^{-1}$ plots treatments as compared to the unfertilized plot.

Table 5: Main effect of $N$ fertilizers on total onion fresh bulb yield

\begin{tabular}{ll}
\hline Treatments & Total bulb yield per hectare (tone) \\
\hline Nitrogen $\left(\mathbf{k g ~ h a}^{\mathbf{- 1}}\right)$ & \\
0 & $13.29 \mathbf{d}$ \\
50 & $14.39 \mathbf{c}$ \\
100 & $16.52 \mathbf{b}$ \\
150 & $17.41 \mathbf{a}$ \\
\hline SE $( \pm)$ & 0.1111 \\
LSD & 0.2533 \\
\hline CV $(\%)$ & 3.46 \\
\hline
\end{tabular}

Means in a column followed by the same letter(s) are not significantly different at $5 \%$

\section{Harvest index}

The results from Table 6 revealed that main application of $\mathrm{N}$ had shown a highly significant $(\mathrm{P}<0.001)$ difference on the harvest index of onion plants. Maximum application of $\mathrm{N}$ at $150 \mathrm{~kg} \mathrm{ha}^{-1}$ increased the harvest index by about $17.6 \%$ over the respective checks. The observed harvest index improvement could be attributed to an increased photosynthetic area in response to $\mathrm{N}$ fertilization that enhanced assimilate production and partitioning to the bulbs. The investigation of Anwar et al. (2001) and Abdissa et al. (2011) on onion supports this result.

Table 6: Harvest indexes of Onion plant as influenced by applications of $N$

\begin{tabular}{ll}
\hline Treatments & Harvest index \\
\hline Nitrogen $\left(\mathrm{kg} \mathrm{ha}^{-\mathbf{1}}\right)$ & \\
0 & $0.66^{\mathrm{d}}$ \\
50 & $0.73^{\mathrm{c}}$ \\
100 & $0.77^{\mathrm{b}}$ \\
150 & $0.80^{\mathrm{a}}$ \\
\hline $\mathbf{S E}( \pm)$ & 0.01 \\
$\mathbf{L S D}(\mathbf{0 . 0 5})$ & 0.0203 \\
$\mathbf{C V}(\%)$ & 5.88 \\
\hline
\end{tabular}

Means in a column followed by the same letter(s) are not significantly different at $5 \%$

\section{Quality Parameters of Onion Bulb}

Total soluble sugars content (TSS)

Regarding the total soluble sugars content (TSS), the application of $\mathrm{N}$ had shown a highly significant (Table 7) difference. The highest TSS value $\left(10.84{ }^{\circ}\right.$ Brix $)$ was recorded in the application of $\mathrm{N}$ at the rate of $150 \mathrm{~kg} \mathrm{ha}^{-1}$; while the minimum TSS value $\left(8.58^{\circ} \mathrm{Brix}\right)$ was recorded in control treatments. Regardless of the levels, maximum application of $\mathrm{N}\left(150 \mathrm{~kg} \mathrm{ha}^{-1}\right)$ increased the TSS by about $30 \%$ as compared to control $\left(8.58^{\circ} \mathrm{Brix}\right)$. 
Table 7: Effects of Nitrogen on TSS of onion bulb

\begin{tabular}{ll}
\hline Treatments & Total soluble solid ( ${ }^{\circ}$ brix) \\
\hline Nitrogen $\left(\mathbf{k g ~ h a}^{-1}\right)$ & \\
0 & $8.58 \mathbf{d}$ \\
50 & $9.35 \mathbf{c}$ \\
100 & $10.45 \mathbf{b}$ \\
150 & $10.84 \mathbf{a}$ \\
\hline SE $( \pm)$ & 0.113 \\
LSD & 0.222 \\
\hline CV $(\%)$ & 4.41
\end{tabular}

Means in a column followed by the same letter(s) are not significantly different at $5 \%$

Bulb shape index

Considerable variation was observed in the result of bulb shape index. The shape of onion bulb can vary from flat to globe to torpedo which is in different markets having different requirements. The onion bulb shape was assessed by the bulb shape index; this was determined by the ratio of bulb length to diameter. The result of this study revealed that application of $\mathrm{N}$ at different levels had shown a highly significant $(\mathrm{P}<0.001)$ difference on the bulb shape index, while their interaction did not (Table 8). This result also showed that the null and lower application of $\mathrm{N}$ fertilizers increased the percentage of shape rejects as compared to the plot received higher levels of $\mathrm{N}$ ( 150 $\mathrm{kg} \mathrm{N} \mathrm{ha}^{-1}$ ). Similarly, Geremew (2009) reported as bulb shape of onion is affected by mineral nutrients.

Table 8: Bulb shape index as affected by main effects of $N$

\begin{tabular}{ll}
\hline Treatments & Bulb shape index \\
\hline Nitrogen $\left(\mathbf{k g ~ h a}^{-1}\right)$ & $0.84^{\mathbf{c}}$ \\
0 & $0.84^{\mathbf{b c}}$ \\
50 & $0.86^{\mathbf{a b}}$ \\
100 & $0.87^{\mathbf{a}}$ \\
150 & 0.007 \\
\hline $\mathrm{SE}( \pm)$ & 0.021 \\
$\mathrm{LSD}(0.05)$ & 5.15 \\
$\mathrm{CV}(\%)$ & \\
\hline
\end{tabular}

Means in a column followed by the same letter(s) are not significantly different at $5 \%$

\section{Dry matter contents}

Regarding the dry matter contents, main application of $\mathrm{N}$ had shown a highly significant effect, while their interaction did not (Table 9). The increasing levels of $\mathrm{N}$ encouraged bulbs with a significantly higher dry matter contents as compared to the unfertilized plot.

The maximum dry matter content of onion bulb (10.54\%) was recorded with higher application of $\mathrm{N}$ at rate of $150 \mathrm{~kg} \mathrm{ha}^{-1}$. The minimum dry matter contents $(9.26 \%)$ detected in control respectively (Table 9). This finding is in consistent with the result of Mojsevich (2008) and Bekele M (2018) who reported that with the increase of doses of the main fertilizer $\mathrm{N}, \mathrm{P}$ and $\mathrm{K} 70,45,70 \mathrm{~kg} \mathrm{ha}^{-1}$ to $\mathrm{N}, \mathrm{P}$ and $\mathrm{K} 110,75,110 \mathrm{~kg} \mathrm{ha}^{-1}$ caused the increase of dry matter content in bulbs from $14.6 \%$ to $15,5 \%$.

Table 9: Dry matter contents as affected by applications of $N$.

\begin{tabular}{ll}
\hline Treatments & DMC (\%) \\
\hline Nitrogen $\left(\mathrm{kg} \mathrm{ha}^{-1}\right)$ & \\
0 & $9.26^{\mathbf{d}}$ \\
50 & $9.65^{\mathbf{c}}$ \\
100 & $10.19^{\mathbf{b}}$ \\
150 & $10.54^{\mathbf{a}}$ \\
\hline SE $( \pm)$ & 0.09 \\
$\mathbf{L S D}(\mathbf{0 . 0 5})$ & 0.18 \\
$\mathbf{C V}(\%)$ & 3.82 \\
\hline
\end{tabular}

Means in a column followed by the same letter(s) are not significantly different at $5 \%$

\section{Storage Life Parameters of Onion Bulb \\ Bulb storage rots percentage}

$\mathrm{N}$ application had a highly significant $(\mathrm{p} \leq 0.05)$ effect on the bulb rotting percentage during the storage time (Table 10). The highest percent of bulb rot percentage (3.69\%) recorded in the plots received $150 \mathrm{~kg} \mathrm{~N} \mathrm{ha}^{-1}$ and the least bulb rot percentage is recorded with unfertilized plots. (Jones and Mann, 1963) also reported that onion bulbs produced without nitrogen application resulted in lowest rotting $(22 \%)$, while highest rotting (36 to $54 \%)$ was 
recorded in bulbs produced under higher dose of nitrogen. Similarly in India, Singh and Dhankar (1991) also recorded that increasing the rate of applied nitrogen $(\mathrm{N})$ from 50 to $150 \mathrm{~kg} \mathrm{ha}^{-1}$ led to significant increases in storage rots of onion during 4 to 5 months under ambient conditions.

Table 10: Storage rots of bulb (\%) as affected by applications of $N$.

\begin{tabular}{ll}
\hline Treatments & Storage rotten bulbs (\%) \\
\hline Nitrogen $\left(\mathbf{k g ~ h a}^{-\mathbf{1}}\right)$ & \\
0 & $7.78\left(2.38^{\mathbf{c}}\right)$ \\
50 & $9.72\left(2.88^{\mathbf{b}}\right)$ \\
100 & $10.83\left(3.07^{\mathbf{b}}\right)$ \\
150 & $13.89\left(3.69^{\mathbf{a}}\right)$ \\
\hline SE $( \pm)$ & 0.39 \\
$\mathbf{L S D}(\mathbf{0 . 0 5})$ & 0.42 \\
$\mathbf{C V}(\%)$ & 30.08 \\
\hline
\end{tabular}

$\mathrm{NS}=$ not significant; Means in a column followed by the same letter(s) are not significantly different at $5 \%$. Numbers in parenthesis are square root transformations.

\section{Physiological weight Loss Percentage}

$\mathrm{N}$ had a highly significant $(\mathrm{P}<0.05)$ effect on the weight loss percentage of stored onion bulb during the two month storage time (Table 11). Large weight loss percentage (39.53\%) was seen at plot received maximum $\mathrm{N}$ at $150 \mathrm{~kg}$ $\mathrm{ha}^{-1}$. This maximum weight loss may be associated with the resumption of higher incidence of sprouting and rotting presumably through increase in the rate of respiration. Regardless of the level, maximum $\mathrm{N}$ application at $150 \mathrm{~kg}$ $\mathrm{ha}^{-1}$ showed high weight loss percentage (19\%) as compared to the control. Dankhar and Singh (1991) also reported similar result that weight loss of bulbs increased with the increase in the nitrogen level.

Table 11: Percentage weight loss (\%) and bulb sprouts (\%) of onion as influenced by $N$ application

\begin{tabular}{lll}
\hline Treatments & PWL $(\%)$ & Bulb sprouts percentage $(\%)$ \\
\hline Nitrogen $\left(\mathbf{k g ~ h a}^{-\mathbf{1}}\right)$ & & \\
0 & $32.05^{\mathbf{d}}$ & $60.28\left(7.75^{\mathbf{b}}\right)$ \\
50 & $34.48^{\mathbf{c}}$ & $56.39\left(7.49^{\mathbf{c}}\right)$ \\
100 & $37.14^{\mathbf{b}}$ & $59.72\left(7.72^{\mathbf{b}}\right)$ \\
150 & $39.53^{\mathbf{a}}$ & $66.11\left(8.12^{\mathrm{a}}\right)$ \\
\hline SE $( \pm)$ & 0.46 & 0.099 \\
$\mathbf{L S D}(\mathbf{0 . 0 5})$ & 0.92 & 0.202 \\
CV $(\%)$ & 5.50 & 5.55 \\
\hline
\end{tabular}

$\mathrm{NS}=$ not significant; Means in a column followed by the same letter(s) are not significantly different at $5 \%$. Numbers in parenthesis are square root transformations.

\section{Bulb Sprouts percentage and weeks to $50 \%$ bulb sprouts}

Sprouting is physiological change that occurs on bulbs of onion in storage. $\mathrm{N}$ application had shown a significant $(\mathrm{P}<0.001)$ difference on percentage bulb sprouts. The highest incidence of sprouting was seen in the plot received maximum $\mathrm{N}$ at rates of $150 \mathrm{~kg} \mathrm{ha}^{-1}$; while the least record observed from unfertilized plots at the end of two months storage. There are similar reports by Bhalekar et al. (1987) who observed that sprouting was increased with increasing nitrogen levels from 0 to $150 \mathrm{~kg} \mathrm{~N} \mathrm{ha}^{-1}$. Dankhar and Singh (1991) also reported that high dose of nitrogen produced thick-necked bulbs that increased sprouting in storage due to greater access of oxygen and moisture to the central growing point.

\section{SUMMARY AND CONCLUSION}

Onion (Allium cepa L.) is introduced to the agricultural community of Ethiopia in the early 1970's when foreigners brought it in. Currently, the crop is produced at different parts of the country for local consumption. Ethiopia increased onion yield and seed production potential in recent years. Optimum levels practices varies with environment, purpose of the production and variety. Hence, there is no specific recommended agronomic practice including fertilizer rate and type to the study area. The results of the study showed that application of $\mathrm{N}$ had considerable influence on different parameters. All growth and yield properties as well as storage life of the bulbs showed significant differences due to the treatments applied. The result of the experiment indicated that growth, yield, quality and storage life of Bombay Red onion plants was significantly affected by various applications of $\mathrm{N}$. Plant height, leaf diameter, leaf length, number leaves per plant, leaf sheath length, bolters percentage, days to physiological maturity, harvest index, mean bulb weight, bulb length, bulb diameter, TSS (oBrix), DMC (\%) and bulb shape index. Similarly, keeping quality of the onion bulbs like bulb sprouts (\%), weight loss (\%), weeks to $50 \%$ bulb sprouts and storage rots (\%) were highly influenced by application of $\mathrm{N}$ at different levels. The highest total bulb yield per hectare $(17.41 \mathrm{t} / \mathrm{ha})$ was recorded with the plot that received the maximum applications of $\mathrm{N}$ $\left(150 \mathrm{kgha}^{-1}\right)$. Maximum (150 $\left.\mathrm{kgha}^{-1}\right)$ application of $\mathrm{N}$ significantly increased bulb rots (\%), bulb sprouts (\%), 
weight loss $(\%)$ and shorten weeks to $50 \%$ bulb sprout during the two month storage time at ambient storage temperature and humidity.

\section{Conflict of interest}

Regarding the publication of this manuscript, there is no any conflict of interest.

\section{Acknowledgem}

We would heartedly like to thank and praise the Lord Almighty God in giving us strength and wellbeing to successfully complete the study. We also want to thanks for all Jimma University horticulture department staff for all their help and moral support. Finally, all the reference materials used in this paper are dully acknowledged.

\section{RFERENCES}

1. Abdissa, T. Tekalign and L. M. Pant, 2011. Growth, bulb yield and quality of onion (Allium cepa L.) as influenced by nitrogen and phosphorus fertilization on vertisol. growth attributes, biomass production and bulb yield. African Journal of Agricultural Research Vol. 6(14), pp. 3252-3258.

2. Aklilu, S.1997. Onion research and production in Ethiopia. Acta Horticulturae 433, 95-97.

Amans, E.B., M.K. Ahmed and J.Y. Yayock, 1996. Effect of plant spacing nitrogen rates on early and late-sown dry season onion (Allium cepa) in the Sudan Savanna of Nigeria Growth, maturity and bulb yield. Ph.D. Thesis. Ahmadu Bello University, Zaria.

3. Anwar MN, Sarker JU, Rahman M, Islam MA, Begum M (2001). Response of onion to nitrogen, phosphorus, potassium, sulphur \& zinc. Bangladesh J. Environ. Sci., 7: 68-72.

Archer J (1988). Crop Nutrition and Fertilizer Use. Second Edition. Farming Press Ltd. Wharfedaale Road, Ipswich,

4. Suffolle. Sharma, J.P. \& Aggarwal.(2002). Sulphur A boon in agriculture. Intensive Agriculture, 2:30-32.

5. Bekele M. Effects of different levels of potassium fertilization on yield, quality and storage life of onion (Allium cepa L.) at Jimma, Southwestern Ethiopia.. J Food Sci Nutr. 2018;1(2):32-9

6. Bhalekar, M.N., P.B. Kale and L.V. Kulwal, 1987. Storage behavior of some onion varieties (Allium cepa L.) as influenced by nitrogen levels and pre harvest spray of maleic hydrazide. Journal Pkv Res. 11(1): 38-46.

7. BPEDORS. 2000. Physical and socio economical profile of 180 District of Oromia Region.Bureau of Planning and Economic Development of Oromia Regional state, Physical planning Development. Finfinne, Ethiopia. Pp.248-251.

8. Brady, N.C. and R.R. Weil, 2002. The nature and properties of soils. Thirteenth edition. Pearson Education Asia. Delhi, India. 960p.

9. Brewster, J.L., 1994. Onions \& Other Vegetable Alliums. CABI Publishing. Wallingford, UK. 236p.

10. Brewster J.L. and H.D. Rabinowitch (ed.), 1990. Onion and allied crops, vol. III. Biochemistry, Food science and Minor crops. CRC press. Boca Raton. FC. 298p.

11. Bungard RA, Wingler A, Morton JD, Andrews M (1999). Ammonium can stimulate nitrate and nitrite reductase in the absence of nitrate in Clematis vitalba. Plant Cell Environ., 22: 859-866.

12. Chung, B., 1989. Irrigation and bulb onion quality. Acta Horticulture 247: 233-237.

13.Dankhar, B.S and J. Singh, 1991. Effect of Nitrogen, Potash and Zinc on storage loss onion bulbs (Allium cepa L.). Journal of Vegetable Science 18:16-23.

14. El-Shaikh, K.A.A. (2005). Growth and yield of onion as affected by biofertilization, application of nitrogen \& phosphorus fertilizers under South Valley. Assiut J. Agric. Sci., 36(1): 37-50.

15. Getachew, T., Eshetu, D., and tebibew, D. 2009. Shallot and Garlic Production guide (Amharic). Ethiopian Institute of Agricultural research, Debre Zeite.52pp.

16 Girigowda, J. R., Narasegowda, N. C. \& Krishna, H. C., 2005, Effect of fertilizer levels on uptake of primary nutrients \& bulb yield of onion hybrids. Mysore J. Agric. Sci. 39(4): 557-560.

17. Gomez, K.A. and Gomez, A.A. 1984. Statistical procedures for Agricultural research. $2^{\text {nd }}$ ed. John wily \& Sons, New York.

18. Greenwood, D. J. and Stone. D. A. 1998. Prediction and measurement of the decline in the critical-K, the maximum $\mathrm{K}$ and total plant cation concentration during the growth of field vegetable. Annals of Botany. 82, 871-881.

19. Jilani MS (2004). Studies on the management strategies for bulb \& seed production of different cultivars of onion (Allium cepa L.). PhD thesis, Gomal University, Dera Ismail Khan.

20. Khan, H.M. Igbal, A. Ghaffoor and K. Waseem, 2002. Effect of various plant spacing and different levels of nitrogen on the growth and yield of onion (Allium cepa L.). J. Biological Sci., 2: 545-547.

21. Kashi, A. and B.R. Frodi, 1998. Effect of nitrogen on the yield, quality and storability of edible onion cultivars (Allium cepa L.) Iran. J. Agric. Sci., 29: 589-597.

22. Kumar, H.J., V. Singh, K. Ajay, S. Mahak, A. Kumar and M. Singh, 1998. Studies on the influence of nitrogen 
on growth and yield of onion CV. Patna Red. Indian J. Agric. Res., 32: 88-92.

23. Lemma D. and Shimeles, A.. 2003. Research experiences in onions production. Research report No. 55, EARO, Addis Abeba Ethiopia, pp. 52.

24. Lemma D. 2004. Onion Production Pamphlet (Amharic version). EARO, Melkassa Research Center.

25. Marschner, H., 1995. Mineral Nutrition of Higher Plants, 2nd ed. Academic press. London.196p.

26. MoARD. 2009. Crop Variety Register. Crop Development department, Issue No.9, June 2009, Addis Ababa, Ethiopia.

27. Mojsevich, N.V. 2008. Influence of fertilizers on yielding capacity and quality of annual onion crops. Ovoshchevodstvo (Belarus) no. 15.

28. Nasreen S, Haque MM, Hossain MA, Farid ATM (2007). Nutrient uptake and yield of onion as influenced by nitrogen and sulphur fertilization. Bangladesh J. Agric. Res., 32(3): 413-420.

29. Shaheen, A.M.; Fatma, A. Rizk and S.M. Singer (2007). Growing onion plants without chemical fertilization. Research J. of Agric. and Biological Sci., 3(2): 95-104.

30. Singh T, Singh SB, Singh BN (1999). Effect of nitrogen, potassium and green manuring on growth \& yield of rainy season onion (Allium cepa, L.). Narendra Deva J. Agric. Res., 4(1): 57-60

31. Yadav RL, Sen NL, Yadav BL (2003). Response of onion to nitrogen and potassium fertilization under semiarid condition. Indian J. Hort., 60(2): 176-178.

32. Yamasaki A, Tanaka K (2005). Effect of nitrogen on bolting of bunching onion (Allium fistulosum L). Hort. Res. (Japan), 4(1): 51-54. 